Ann. Zootech.. 1980. 29, no h. s., 383-421.

\title{
Belgian energy and protein feeding standard; for growing and fattening cattle
}

\author{
Ch. V. BOUCQUE, L.O. FIEMS, B.G. COTTYN and F.X. BUYSSE
}

National Institute for Animal Nutrition, Scheldeweg 68, B 9231, Melle-Grontrode (Belgium).

\section{Energy}

In Belgium, the energy value of feedstuffs for beef cattle is still expressed as starch units. Nevertheless, there are no standards (energy - requirements) proposed to obtain a certain daily liveweight gain at a well defined liveweight interval.

In practice, fattening animals are fed to appetite on a complete dry diet, besides straw or a restricted quantity of hay (to prevent rumen fermentation disorders) on the one side, and on a mixed ration based on roughages and concentrates on the other hand. Therefore energetic feedstuffs are used such as cereals (BUYSSE et al., 1966; BUYSSE and EECKHOUT, 1970 ; CotTYN et al., 1976), sugar beet pulp (Boucque et al., 1976 ; 1978), fodder beets (COTTYN et al., 1970) and maize crops (BoucQue et al., $1976 ; 1978$ ), which assure a high daily gain. To reach a growth level of $1100 \mathrm{~g}$ per day with store bulls, the fattening diets should have an energy content of at least 60 per cent starch equivalents in the dry matter. As shown in Table 1, an ad libitum intake of these diets did not result in fat carcases with Belgian breeds (white blue $=$ BWB, and white red $=$ BWR breed).

\section{Protein}

Crude protein and digestible crude protein are used to express the protein requirements for beef cattle. The protein requirements described by the CVB (1979)) of the Netherlands are often used. At the National Institute for Animal Nutrition BuYsSE and EeckHout (1970) and EECKHOUT and BuYSSE (1972) investigated the protein requirements of rapidly growing young bulls (baby-beef type) of the Belgian white red breed, ad libitum fed with cereal based diets supplemented with soyabean meal.

They found that within the liveweight range of $200-350 \mathrm{~kg}$, a digestible crude protein content of 10.3 per cent (11.2 per cent crude protein) in concentrate diets (corresponding with 11.9 and 12.8 per cent in the dry matter respectively) resulted in a reduction of the growth rate and an unfavourable feed conversion, while the feed intake was not depressed. Between 350 and $480 \mathrm{~kg} 10.3$ per cent digestible crude protein (11.2 per cent crude protein) in the concentrate diet (based on 82 and 92 per cent cereals) was sufficient for maximum growth ; daily feed intake was significantly higher compared to the 14.2 per cent digestible crude protein level (15.2 per cent crude protein) ; feed conversion was not significantly different. The performances are summarised in Table 2.

BouCQUE Jet al. $(1978 ; 1979)$ investigated the impact of the protein content in the ration on the performances of fattening store bulls with dried sugar beet pulp diets and maize silage diets. A content of 7.9 and 8.4 per cent digestible crude protein (12.1 and 12.2 per cent crude protein) in the dry matter and a daily digestible crude protein intake of 6.2 and $6.9 \mathrm{~g} / \mathrm{kg} \mathrm{W}^{0.75}$ resulted in daily gains of 1108 and $1269 \mathrm{~g}$ for maize silage and dried sugar beet pulp rations respectively. The explanation of this discrepancy must be found in a different energy intake of ca $7 \mathrm{~g}$ starch units per $\mathrm{kg} \mathrm{W}^{0.75}$. There is good evidence that there is also a difference in protein degradability between maize silage and dried sugar beet pulp (MerTeNs, 1977). Further research is necessary. 
TABLE 1

PERFORMANCES OF FATTENING STORE BULLS ad libitum FED WITH SEVERAI. ENERGETIC DIETS

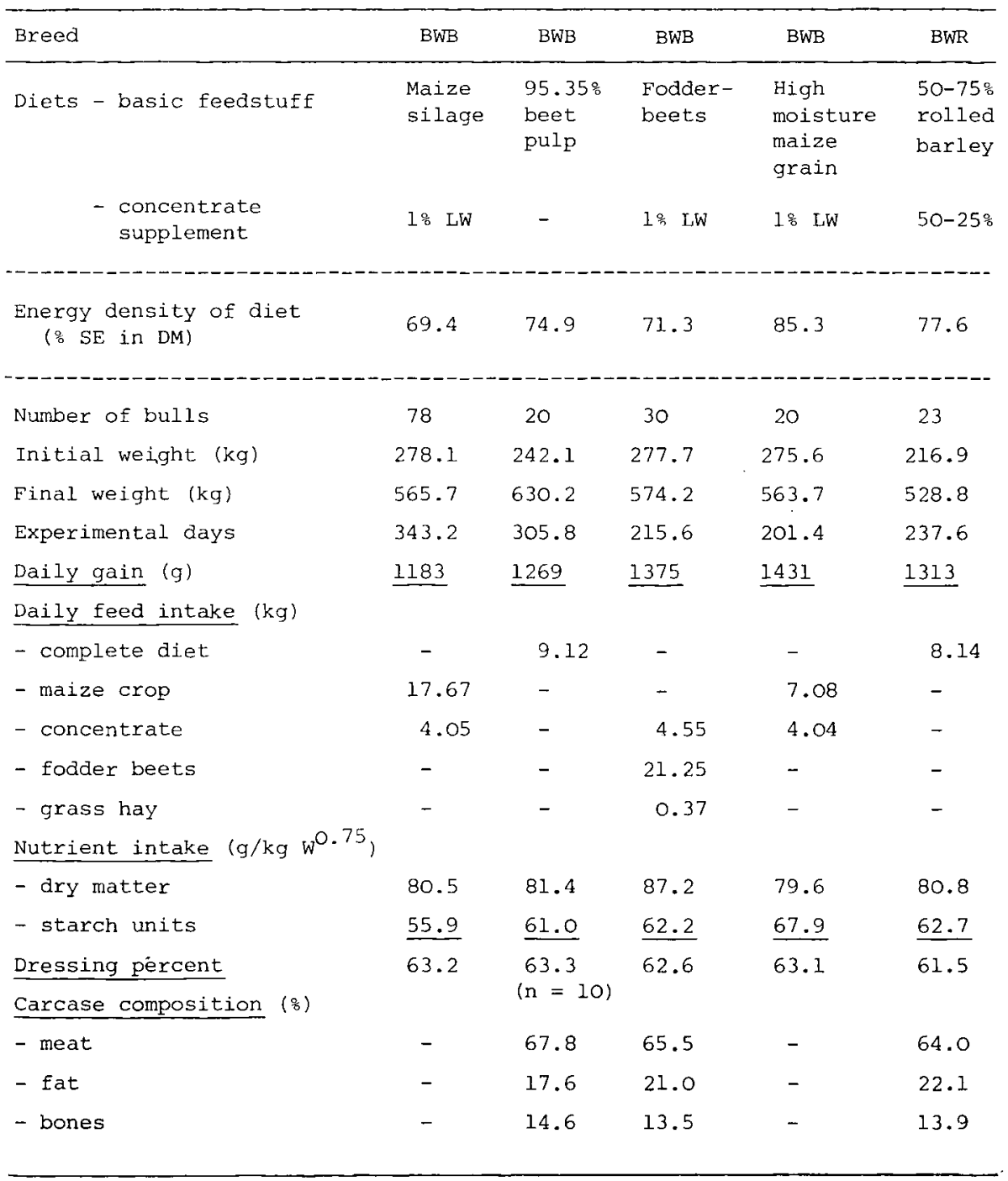




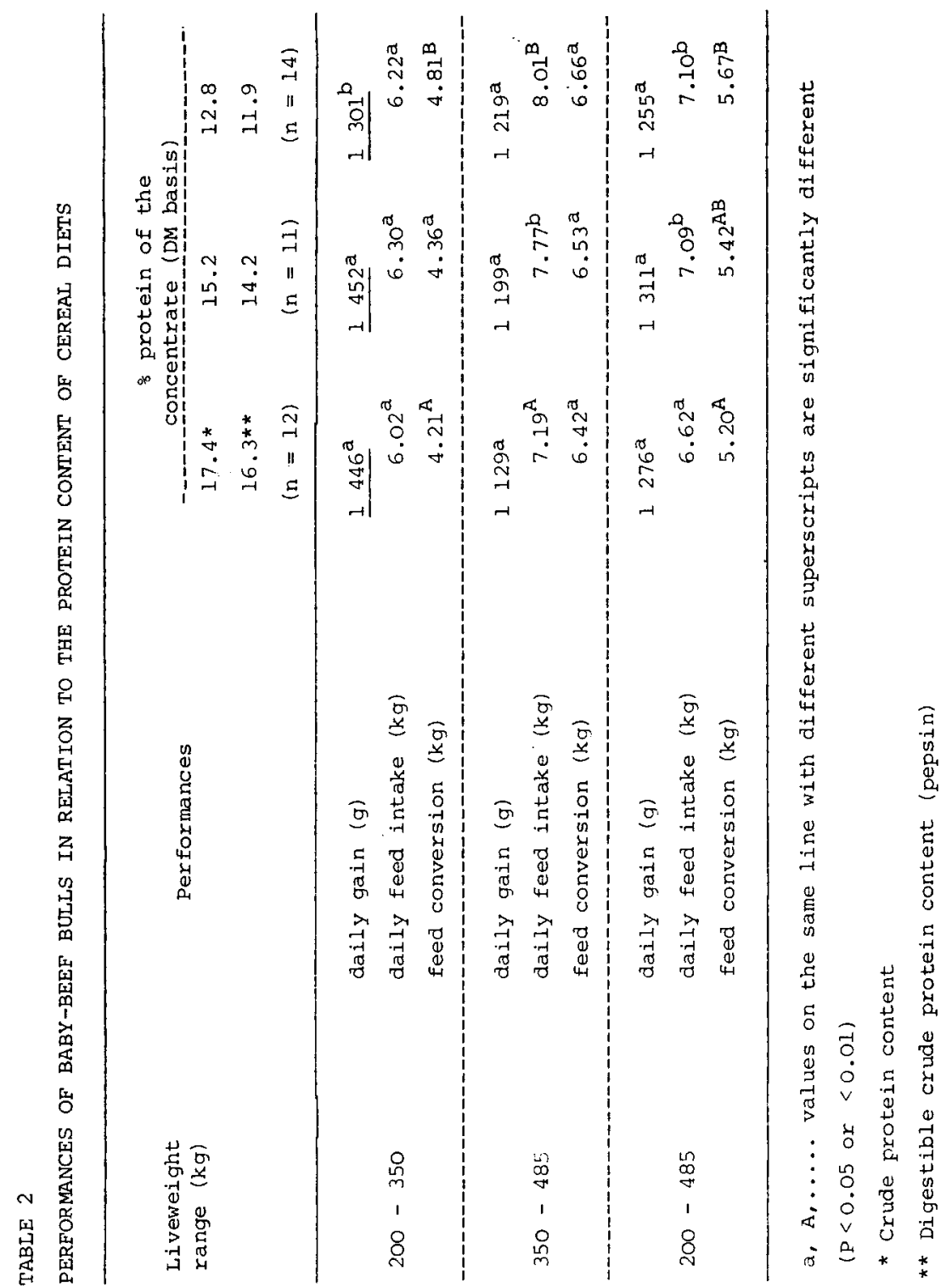


TABLE 3

EFFECT OF PROTEIN LEVEL ON GROWTH RATE AND FEED EFFICIENCY OF FATTENING STORE BULLS

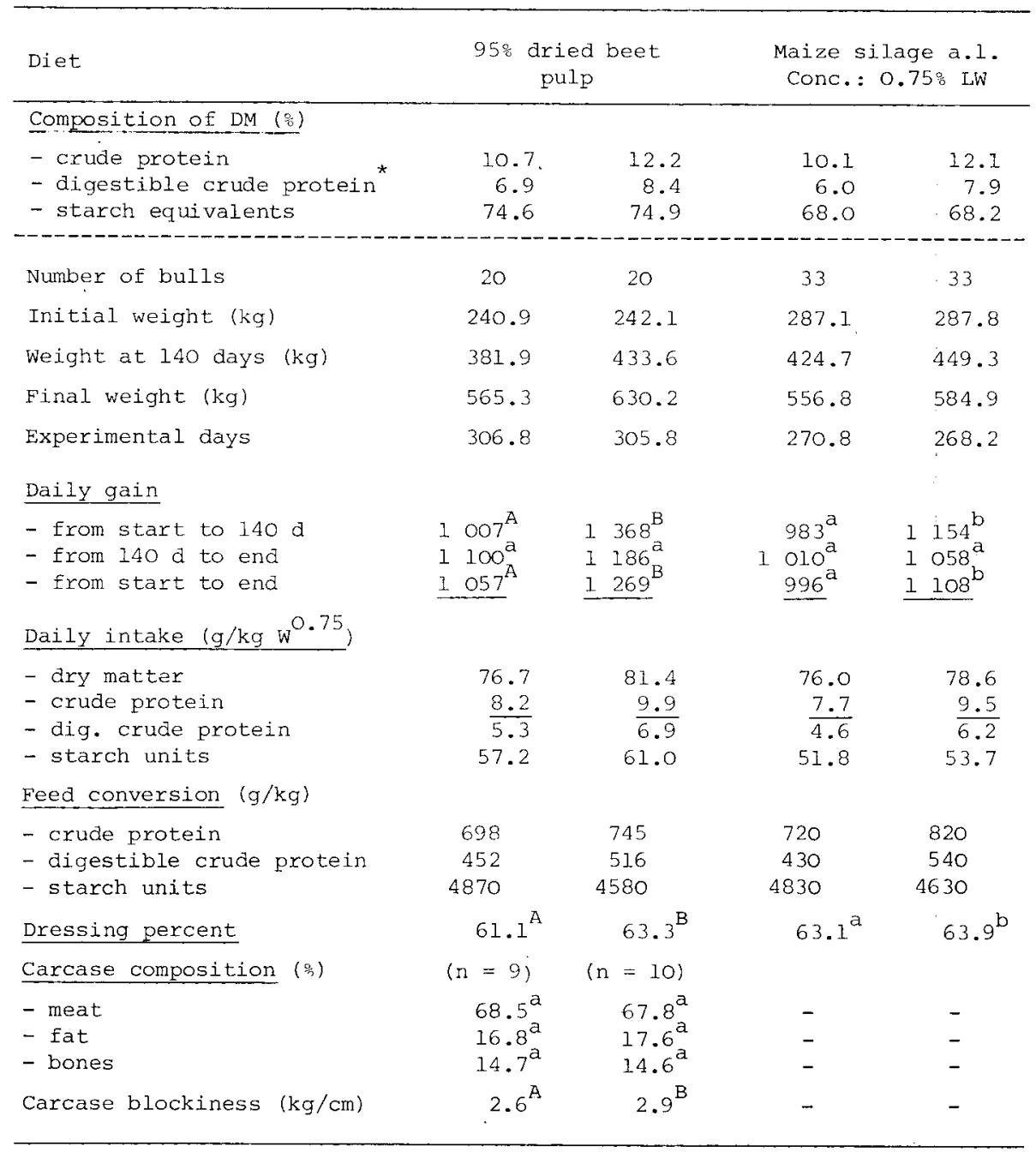

a, A .... values on the same line with different superscripts are significantly different $(P<0.05$ or $<0.01)$

$\star$

Determined with sheep in digestibility trials. 
LAMBOT et al. (1979) found comparable results : the optimum crude protein concentration for growth and nitrogen utilisation is about $13.3-12.2$ and 11.4 per cent at body weights of 250,350 and $450 \mathrm{~kg}$. The effect of the ration protein content is presented in Table 3 .

\section{References}

Boucque Ch. V., Cotryn B.G., Buysse F.X. 1976, Maize silage with or without NPN, dehydrated whole-crop maize pellets or high moisture maize grain for finishing bulls. Anim. Feed Sci. Technol., 1, 347.

Boudque Ch. V., Cottyn B.G., Aerts J.V., Buysse F.X., 1976. Dried sugar beet pulp as a high energy feed for beef cattle. Anim. Feed Sci. Technol., 1, 643.

Boucque Ch. V., CotTyn B.G., BuYsse F.X., 1978. Bull fattening with dehydrated wholecorn-plant pellets compared with corn silage and high-moisture grain. Proc. 2nd International Green Crop Drying Congress, August, 1978 p. 327.

Boucque Ch. V., Fiems L.O., CotTyn B.G., Buysse F.X., 1978. Utilization of some industrial by-products in beef production. European Congress for Improved Beef Productivity, Paris, 28-29 September 1978.

Boucque Ch. V., 1979 . Unpublished data.

Buysse F.X., Boucque Ch. V., Eechout W., 1966. Intensive beef production (baby-beef) principally on concentrates. Communication of the Institute No. 125.

Buysse F.X., Eeckhout W., 1970. Besoins en protéines de jeunes taureaux soumis à un régime d'engraissement intensif. Rev. Agric. Brux., 23, 703.

Cottyn B.G., Bouceue Ch. V., Buysse F.X., 1970. La valeur des betteraves fourragères pour la production intensive de viande bovine. Rev. Agric., Brux., 23, 501.

CotTyn B.G., Bouceue Ch. V., Buysse F.X., 1976. Complete dry rations based on dried sugar beet pulp and rolled barley for intensive beef production. Z. Tierphysiol., Tierernährg. u. Futtermittelkde. 37, 99.

CVB., 1979. Voedernormen voor de landbouwhuisdieren en voederwaarde van veevoeders. Verkorte tabel. Centraal Veevoederbureau in Nederland.

Eeckнout W., BuYsSE F.X., 1972. Recherches complémentaires concernant les besoins en protéines de taurillons (baby-beef) engraissés de manière intensive. Rev. Agric. Brux., 25, 21.

I ambot O., Bienfait J.M., Van Eenaeme C., Nicks B., Cordiez E., 1979. Etude de trois niveaux protéiques dans des régimes à base de maïs déshydraté pour des jeunes bovins en croissance - engraissement. Ann. Méd. Vét., 123, 195.

MERTENS D.R., 1977. Importance and measurement of protein insolubility in ruminant diets. Proc. Georgia Nutrition Conference, p. 30.

\section{Danish energy and protein feeding standards for growing and fattening cattle}

\section{H. REFSGAARD ANDERSEN and J. FOLDAGER}

The National Institute of Animal Science

Rolighedsvej 25, DK 1958 Copenhagen V, Denmark

\section{Introduction}

In Denmark the energy value of feeds as well as the energy requirements of growing animals and milking cows are still expressed as Scandinavian Feed Units (SFU). One SFU is equivalent to the energy content of $1 \mathrm{~kg}$ barley ( 85 per cent dry matter). The advantages of this system are the additivity of energy values of feeds, the simplicity of estimating ration composition for a given production, and the expected production from a defined ration.

The requirements for protein are expressed as digestible crude protein (DCP). 